\title{
COMMERCIAL AND ECONOMIC RELATIONS \\ OF RUSSIA AND ENGLAND / GREAT BRITAIN \\ AS THE MOTIVATIONAL DRIVERS TO THE RUSSIAN LANGUAGE \\ LEARNING
}

\author{
Assoc. Prof. Nataliia Grishchenko, \\ Assoc. Prof. Evgeniya Ershova ${ }^{1}$, \\ Assoc. Prof. Mariya Starsheva ${ }^{1}$, \\ ${ }^{1}$ Siberian Federal University, Russia
}

\begin{abstract}
The article offers the brief review of the long term English-Russian relations identifying the first target audience of the Russian language learning, the purpose of it, the methods of learning being used and the tools of the Russian language promotion. The attention is focused on the role of commercial and economic relations of Russia and England / Great Britain in promotion of the Russian language on the territory of Great Britain which are regarded as one of leading motivational drivers for the Russian language studying by the British. As the proof to this theory the article offers the analysis of some professionally focused Russian textbooks, created in England / Great Britain, for English-speaking audience since XVI century. The analysis of more than 200 scientific courses (including the Russian language lexicons, dictionaries, manuals, grammars, reading textbooks) reveals the gradually changers in structure and content of the Russian language literature from the XVI century up to the first half of the XX century.
\end{abstract}

Keywords: commercial and economic relations, missionaries of Russian language, lexicons and dictionaries, professional focused (business) Russian language.

\section{INTRODUCTION}

Strong commercial and economic relations between Russia and England / Great Britain can be referred to the main reasons of the Russian language learning in this country. Having possessed the vast territory and rich natural recourses Moscow state was considered by England to be the reliable and beneficial partner ever since the XVI century. Russia was interested in relations with such a well-developed partner as well. It is proved by the numerous privileges given to English subjects by Ivan the Terrible [12]. The combination of these historical facts gives us the right to confirm that the relations between England and Russia in the commerce sphere were considered as mutually beneficial.

\section{MATERIALS}

Since the initial interest of England to Russia was based on the commercial relations and remained so for centuries, it is logical to assume that the first people, aspired to study the Russian language and the culture of Russia, were tradesmen and ambassadors. The proof can be found in the travel notes of the Englishmen, arrived in Russia in 1553. The notes contain the information about the first attempts of the Russian language 
learning by the agents of the "Moscow Company" by means of direct communication with locals [7]. It is known that many representatives of this company knew the Russian language. Being the young assistants, they arrived in Russia and stayed there for many years studying the language and the way of life of locals for the successful business [13].

The abstract from the regulations of the "Moscow Company" proves this fact as well as reveals the intentions of England toward Russia and shows the significance of these relations for England. According to the regulations the agents had to get to know about the currency, weight, measure, count used on the territory of Russia; the goods needed; "to know the natures, dispositions, laws, customs, manners and behaviours of the people of the countries where they shall traffic, as well of the nobility as of the lawyers, merchants, mariners, and common people, and to note diligently the subtleties of their bargaining, buying and selling, making as few debts as possible may be; and to be circumspect, that no law, neither of religion, nor positive, be broken or transgressed by them, or any minister under them, nor yet by any mariner, or other person of our nation; and to foresee that all tolls, customs and such other rights, be so duly paid, that no forfeiture or confiscation may ensure to our goods either outward or inward; and that all things passed with quiet, without breach of the public peace or common tranquility of any of the places where they shall arrive or traffic" [7].

The mention of precisely the commercial interests can be found in one of the first works introduced Russia to the English - G. Fletcher "Of the Russe common wealth". This report gives the detailed information about all spheres of life in Russia, which was the important option for the choice of the export goods. At the same time the author lists the goods produced on the territory of Russia and could be imported to England: fat, fur, wax, honey, cow's leather, salt, wood, saltpeter, iron and so on. Besides, the information about the taxes, the state of the tsar's treasury and the ways of its replenishment is made a separate chapter [6]. Taking into consideration the above, it can be certain that the interest from England to Russia had the practical character and referred to the commercial sphere mainly (export and import).

M. P. Alexeev, the well-known scholar in the history of the Russian language, mentioned the Russian language learning with the practical purpose as the primary target for that period. In the article "The Russian language in the world" M. P. Alexeev focuses on the fact that since the beginning of the XVI century the Russian language learning with the practical purpose became popular with tradesmen of the Western Europe [1]. The emergence of the Russian language dictionaries, manuals, grammars at the end of the XVI century (mainly handwritten) can be considered as the evidence of this fact.

In this regard, it seems appropriate to mention the "Russian-English Dictionary" by Richard James (1618-1620), the document, which was the important source of information about Russia and its language for the English. It is necessary to say that the colloquial Russian was taken as the base for it. This dictionary is the clear reflection of everything that was heard by the author himself in such trade towns as Archangelsk and Kholmogori: the variants of the dialects.

The clear and sharp characteristic of this dictionary is given by S. K. Miloslavskaia, who defined it as "the first step of Business Russian" in England [11]. The scholar points out that this dictionary took the important place among the practical manuals for 
tradesmen, which is proved by the numerous commercial terms offered in it. S. K. Miloslavskaia underlined the accuracy of the vocabulary selection. Along with the measure of length, capacity, area, Russian currency, the system of count, numbers, the list of import and export goods, the colloquial set expressions necessary for the successful communication concerning trade, the dictionary offered the information which helps imagine the rout of the English tradesmen to the Moscow state and their movement within it. R. James listed the most important winds for the trade vessels, the central trade towns of Russia and navigable rivers [11].

Apart from the tradesmen, a lot of other foreigners were interested in the Russian language learning as having arrived in Russia they were welcomed and stayed there for years. It is a well-known fact that the inflow of the foreign specialists was closely connected with the reign of Peter the Great (1682-1725). It was the precise period which ignited the necessity of the Russian language learning by foreigners, as well as the foreign languages by Russian people. The great number of text-books, grammars, manuals of the Russian language for the French and the German were created at that time. In Great Britain at the end of the XVII century the "Original and valuable grammar of the Russian language" was written by H. Ludolf [1]. The learning of the Russian language, from the author's point of view, had the great practical value and was the primary target for England because of the economical and political reasons. The preface of the book proves this. The author wrote about the spreading of the Russian language not only within the territory of Russia but far beyond it [10].

It is known that many Russian rulers considered the relations with Europe as desirable and necessary for the further prosperity of the state. J. Bowring English politician, linguist and translator, characterizing the reign period of Alexander I (1801-1825) in his diary, wrote that the influence of Europe had been felt a lot: the foreigners took the highest positions in the Government, educational and economical sphere. By the year 1877 (the year of the publication) the situation had been slightly changed. But never the less, J. Bowring still mentioned the significance of the foreigners for the industry of Russia [4].

The fact that until the XIX century the Russian Grammar by H. Ludolf remained the only text-book written for the English proves the usage of direct method of the Russian language learning at that time [8]. However the publication of dictionaries (including the commercial dictionaries) was carried on both in Russia and in Great Britain since the XVIII century [5].

The beginning of the XIX century was marked with the works of the Russian language missioners such as J. A. Heard and $\mathrm{Ch}$. Ph. Reiff. However their text-books were focused on the general topics and revealed the economic-commercial tendency of the Russian-English relations only to some extent. Probably, it can be explained by the fact that the authors of the text-books considered the Russian language as the element of the national culture rather than the tool for getting profit in the sphere of commerce. In the second part of the XIX century in Great Britain the publishing of the Russian language text-books for specific purposes started. They comprised the vocabulary, dialogues and texts on the topic of commerce.

Among of these text-books was the Russian language Grammar by A. A. Ivanov (Ivanov A. A. Russian language Grammar: translated by Gowan, Walter E. - London, 1882. - 158 p.) written in Russian in 1861 and translated in English in 1882., which can 
be viewed as the evidence of the demand such text-books in Great Britain. The grammar partly informed the students about the rules of the business correspondence in Russia. The addresses (such as: ЕГО ИМПЕРАТОРСКОЕ ВЕЛИЧЕСТВО ГОСУДАРЬ ИМПЕРАТОР АЛЕКСАНДР АЛЕКСАНДРОВИЧ, Его Императорское $u$ Королевское Высочество Император Германии и Король Прусский Вильгельм, Генерал Фельдмаршал, Ваше Сиятельство и т. д.), set expressions (Я просил Вас о доставлении мне Ваших планов...), the names of the state institutions (Государственный Совет, Канцелярия министерства Внутренних Дел) $)^{1}$ necessary for the business letters and petitions are given as the examples.

The similar structure can be observed in the other Russian language text-books of that time. The remarkable one is "Russian conversational-grammar", (Motti P. Russian conversation-grammar. - London, 1890. - 387 p.), the author of which, P. Motti, focused his attention on the importance of the Russian language learning for the purpose of achieving better results by the British precisely in the commercial sphere. One of the parts of this text-book comprises "the set expressions for business" and the detailed information about the business correspondence: the examples of business letters, bills of exchange, the attorney letters, invoices, declarations in Russian and in English. As an appendix the table of weights, measures and Russian monetary units were given.

C. A. Thimm, the author of the Russian language text-books, published at the beginning of the XX century, marked the practical focus of the Russian language learning by the British as well, underlined that "Russia geographically, politically, and commercially is expanding and developing rapidly and it becomes every year of greater importance for politicians, officers of both cervices and civil administrators, as well as for commercial men, to be acquainted with its language" [14].

In the preface of the manual, C. A. Thimm wrote that the first country which had recognized the necessity of the Russian language learning was Germany [14]. To Great Britain the understanding of this necessity came only at the end of the XIX century. C. A. Thimm wrote that if Great Britain wanted to collaborate successfully with such "Power" (Russia), the Russian language for the specific purpose should be started learning at school. Proving this and preparing the students for achievement of the certain goal - to learn the language for the establishment of the commercial relations with Russia - the manual (Thimm C. A., Marshall J. Russian Self-Taught with phonetic pronunciation, $2^{\text {nd }} e d$. - London, 1904. - 134 p.) introduces such parts for self-learning as: business and crafts, commercial and trade terms, business correspondence (this part consists of the lists of the words and set expressions with the English translations and transliteration). Further for the detailed study the dialogues "For the commercial agents" are offered. They provide foreigners with the vocabulary, enough for the convenient staying in Russian and starting of the successful business relations there. The author gave the detailed description of the following situations: arrival, check-in at the hotel, breakfast, lunch, possible situations in the city, correspondence, shopping, tailor, shoemaker, inquiries, money exchange, at the post, railway and travelling by ship. It is necessary to mention that for better understanding the manual offered the additional

\footnotetext{
${ }^{1}$ HIS IMPERIAL MAJESTY STATE EMPEROR ALEXANDER ALEXANDROVICH; His Imperial and Royal Highness, the Emperor of Germany, the King of Prussia Wilhelm; General Field Marshal; Your Excellency; I asked you for the delivery of your plans to me ...;The State Council; the Chancellery of the Ministry of Internal Affairs.
} 
information in English (as the reference in the footnotes): the necessary data for buying the private or trade license, the detailed instruction, prices and so on. The students are given the information about the metric system in Russia, Russian monetary units, exchange rate: Russian to English and American currency.

In this regard one more manual should be examined - Bondar's simplified Russian method (conversational and commercial). - London, 1911. - 292 p. - the Russian language business correspondence course (terms, different types of business letters). As the final step of the manual the business texts for reading skills development are offered. According to D. Bondar, after careful study of the manual the students get the knowledge of the Russian grammar and vocabulary enough for the active communication and business letters writing [3]. Offering the vocabulary of everyday and business communication in his manual, the author underlines the practical purpose of the language learning and says that the knowledge of the Russian language is becoming more and more essential because of the constant English-Russian relations development in social and business spheres [3].

It is important to highlight that whereas in the Russian language text-books written before XX century the general vocabulary was dominated and the commercial terminology was introduced only in an insignificant amount in the form of a few phrases, dialogues, some sections of the textbook, at the beginning of the XX century the text-books of the new type started to appear. They were the professionally-oriented business language text-books.

As the example of such text-books, the manual of Russian commercial correspondence by M. Sieff can be given (Sieff M. Manual of Russian commercial correspondence: $2^{\text {nd }}$ ed. - London, 1914. - 232 p.). The practical orientation of this manual is shown in the narrow-profile choice of material. The manual does not introduce the wide theoretical knowledge of the Russian grammar and pronunciation. This business correspondence oriented manual does not include information about the Russian culture or the Russian literature but gives the vocabulary and information for specific purposes. The target audience of it was the students who had already got some knowledge of language and having or planning to establish business contacts with Russia.

The author starts the manual with detailed study of the business letter structure. The information is given in English with inclusion of some parts of the letter in Russian as the example. The first section of the manual offers the business correspondence phrases (with English translation). There are 17 variants of the business letter opening, for example:

-Осмелюсь довести до Вашего сведения (I take the liberty to bring to your notice); -Я буду Вам весьма благодарен за... (I shall be very thankful to you for...).

Further, the author introduces: confirmation of receipt of a letter (12 cliché), confirming letter dispatched prior to present communication (9), intimation that contents of letter have duly been noted (4), inquiries about the prices and terms (8), replies to inquiries with offers (7), letters with orders (8), invoices and accounts (8), bills of exchange (5), phrases concluding a letter (7).

The second, the third and the forth sections comprise the examples of the business letters (both English and Russian variants are given): correspondence concerning the offering, purchasing, and supplying of goods; correspondence about payment made and 
payment received; correspondence about bills of exchange; correspondence relating to shipping, forwarding and clearing. In appendix the specimens of Russian bills of exchange and promissory notes; tables of the Russian weights and measures, currency and etc; list of abbreviations are given. The brief analysis of the manual has shown that it can be considered as the expressive example of the professionally-oriented text-book.

\section{RESULTS}

Summing up, it is necessary to mention that during the history of the English-Russian relations the commercial and economic ties were undergoing changers but never stopped. The commercial relations became less stable after the death of Ivan the Terrible, the reign of Peter the Great brought strength and power to them. The trade contacts were not broken even in the period of the Crimean war, when Prussia acted as intermediary [9]. Though, it is important to mention that Great Britain was not a monopolist on the Russian market. A lot of European countries, and further America, tried to weaken the position and commercial prestige of Great Britain.

\section{CONCLUSION}

No doubt, the knowledge of the Russian language was necessary for the efficacious business communication in that situation. This fact was constantly mentioned by the authors of the Russian language manuals for English-speaking students and those who were encouraging the promotion of the Russian language in Great Britain (from the XIX century up to the first half of the XX century). The letter, written by one of the members of the Anglo-Russian literary Society, published in "Morning Post" and in the AngloRussian literary Society proceedings № 17 (February, March, April, 1897) prove this. It said: "As in the South American trade knowledge of Spanish is indispensable, so in the Russian trade, if we wish to hold our own, we must master the Russian language" [2].

The brief review of the Russian-English relations as well as the content of the educational literature for the Russian language proves that in this period (from the XIX century up to the first half of the $\mathrm{XX}$ century) the economic-commercial relations between countries were the motivational drivers encouraging the British to learn the Russian language.

\section{REFERENCES}

[1] Alekseev M.P., The Russian language in the world, Questions of linguistics, Russia, vol. 2, pp 3-14, 1984. (in Russian)

[2] Proceedings of Anglo-Russian literary society, The Russian language, GB, vol. 17, pp 7-13, 1897.

[3] Bondar D., Simplified Russian method (conversation and commercial), GB, 292 p., 1915.

[4] Bowring J., Autobiographical recollections of Sir John Bowring with brief memoir by Lewin B. Bowring, GB, 426 p., 1877.

[5] Grishchenko N.A., The Russian language in Great Britain from the XIX century up to the first half of the XX century, Attachment, Russia, issue A.1, pp 1-34, 2014. (in Russian) 
[6] Translations of Hakluyt Society, Russia at the close of the sixteenth century comprising "Of the Russa Common Wealth" by Dr. Giles Fletcher and "The travel of Sir Jerome Horsey" by J. Horsey, GB, 392 p., 1856.

[7] Hakluyt R., The discovery of Muscovy, GB, 192 p., 1889.

[8] Heard J.A., Practical grammar of the Russian language. Key to the themes contained in Heard's Russian grammar, Russia, 323 p., 1827.

[9] Hromov P.A., Domestic and Foreign trade in Russia, Economic history of USSR, Russia, 272 p., 1988. (in Russian)

[10] Larin B., About H. W. Ludolf and his book, Preface and the introductory article to "Grammar" by H.W. Ludolf, Russia, pp 5-40, 1937. (in Russian)

[11] Miloslavskaia S.K., Russian as a foreign language in the history of the formation of the European image of Russia, Russia, 400 p., 2008. (in Russian)

[12] Rambaud A., Rusia.tr. by L.D. Lang, GB, 309 p., 1898.

[13] Seredonin S.M., The composition by G. Fletcher "Of the Russe common wealth" as the historical source, Russia, 399 p., 1891. (in Russian)

[14] Thimm C.A., Marshall J., Russian Self-Taught with phonetic pronunciation, The USA, issue 4, 134 p., 1915. 